\title{
Homeownership Affordability of Low Income Group in Kuala Lumpur
}

\author{
Norizan Rameli \\ School of Government, College of Law, \\ Government and International Studies (COLGIS) \\ University Utara Malaysia (UUM) Sintok 06010, Kedah, Malaysia \\ Dani Salleh \\ School of Government, College of Law \\ Government and International Studies (COLGIS) \\ University Utara Malaysia (UUM) Sintok 06010, Kedah, Malaysia \\ Mazlan Ismail \\ School of Government, College of Law \\ Government and International Studies (COLGIS) \\ University Utara Malaysia (UUM) Sintok 06010, Kedah, Malaysia
}

\begin{abstract}
The housing issue has taken over the global attention particularly homeownership affordability issue. Owning a house is significantly known as one of the basic necessities in human survival. Thus, the capability of the low income group to afford a house is practically the main highlight in this issue. Besides, the escalation of the low income group in the urban areas which occurred due to the migration to enhance a better life causes this issue to be left as a debatable one. Hence, it is important to identify the affordability levels and also the socioeconomic factors which affect the homeownerships affordability of the low income groups in Kuala Lumpur city. The socioeconomic factors were focused on household income, household expenditures, type of employments, the education levels, household sizes, the monthly payment for housing and the household savings. Furthermore, an investigation based on the stratified sampling techniques was carried out on a total of 400 of head households according to their specified residential zones. The indication of the housing affordability level was measured based on the residual income theory whereas the binary logistic regression was implemented in identifying their affordability factors. The results exhibit the low income groups are afforded to own public housing unit in Kuala Lumpur. Household income, household expenditures and monthly payment for housing affect homeownership affordability significantly. Conversely, education level, types of employment, household size and household savings not affects homeownership affordability significantly.
\end{abstract}

Keywords: affordability, homeownership, public housing, low income group, socioeconomic factors

\section{INTRODUCTION}

The need of having a house is the top priority for the citizens to ensure their ongoing lives. A house is vividly symbolises as a place for shelter, to rebuild and nurtured the bond within each family members and a significant place to ease and take a break after going through the tiring day. Furthermore, a house also indicates the stage of happiness which covered up the 
economic and social stabilities of each household. This has caused multiplications in applicants on residences every year, mostly in the urban zones.

The multiplications in applicants on residences were triggered by the rapid urbanization process which gradually increased the number of residents in the city. The immigration among the citizens specifically the low income group to the city has contributed to the abundant of populations there. Accessibility to vary infrastructures and beneficial accommodations, all together with the large jobs' opportunities offered in the city has leaded the low income group to migrate. Thus, the affordability level and socioeconomic factors among the low income group should be analyzed to allocate them an access to homeownership affordability despite of the hardships to balance other living costs.

\section{Affordability determinants}

The affordability concept is a prime as well as the importance of the house as human necessities. Hence, Burke \& Ralston (2004) has defined the ability of housing as the ability of a household to meet with the housing cost while preserving the ability to obtain sufficient daily necessities. This means the affordability concept is widen through all services and products factors which is necessary for the households in life struggles (Stone 2006b). The products and services factors defined including the household expenditures. This concept corroborates the affordability concept highlighted by Chaplin \& Freeman (1999) that deliberate the affordability as a direct relativity between the housing expenditures and the household income. However, in ensuring the affordability viewed through holistic side, the affordability concept should be equalizing the housing cost and non housing cost according income. Nevertheless, the process to reach the equilibrium between the housing cost and non-housing expenditure become the most challenging for the household (Stone, 2006b).

The residual income theory focused on the residues of income after settling payment for housing cost. This method is frequently used by the policy makers to indicate the income support and the household's competence to obtain government subsidy which is implimented in Hong Kong, New Zealand and United States (Gabriel, Jaobs, Arthurson, Burke, \& Yates, 2005; Robinson et al., 2006; Tang, 2012). The residual income theory could indicate whether there's an occurrence of excessive expenditures or payment for housing. This method is used by Thalmann (2003) amongst the tenant samples in Switzerland to estimate the low income household which need specific assistance from the government specifically. With more definite expenditure's distributions from the income, the government is able to identify types of assistance needed by the household. This is due the complications of affordability faced by the low income group are rather essential to handle individually or as a household. The residual income theory identifies the difference of housing cost and income. Hence, the complications of affordability are faced when residues income could not support the non-housing basic necessities after settling down the monthly payment (Stone, 2006a).

\section{Socioeconomic Factors}

The monthly income and property assests turn out to be the main factor that affect the homeownership affordability (Boelm \& Schlottmann, 2004). The higher of monthly income and property assets will increase the homeownership affordability. Thus, it is not deniable that high income group obtain higher chances to homeownership than the low income group 
(Follain \& Ling 1988; Fu, 2015). On the other hand, the low income group faced complications of homeownership due to less monthly income and other socieconomic factors.

The affordability becomes tougher if it depends on the single income. The income are based on the head household income for married status. Meanwhile, the dual-income households between the working spouses encouraged the housing affordability (Scalon\&Whitehead, 2004). For instance, a research by Kupke \& Rossini, (2011) found the homeownership is increasingly difficult in cities such as Adelaide, Melbourne and Brisbane for the single income household. This phenomenon not only happened in Australia cities, but single income household mainly in Germany's cities also encountered the complications of housing affordability to the extent of reducing the homeownership rate in the country (Bentzien et al., 2012).

The non-housing expenditure is also a prime factor which affected homeownership affordability. The household expenditure included several costs in life survivals such as foods, apparels, wellness, educations, investments in human capital (Kutty, 2005), utility payments (Bentzinger\& Cook, 2012) and transportation costs (Kupke \& Rossini, 2011) are the essences in daily household expenditures. Although each household needed the non-housing expenditures in life, the household expenditures and the consumed priorities differ accordingly. Households with children tend to spend the expenditures towards education differ with the households without children.

The education levels have long been used to measure the access to homeownership. This was due to high correlation between the income and education levels which leaded housing affordability (Goodman, 1998; Haurin, 1991). Moreover, higher education levels established more households with homeownership and boosted the homeownership rate in the country (Robinson et al., 2006). In Malaysia, the education levels are relevantly used to indicate the homeownership affordability. Low education level resembled low families income group (Mohit\&Nazyddah, 2011). Through a higher education level, the household could earn occupations with best income because the household income depends on the capability of human capital or the household education level (Tumer \&Luea, 2009).

In addition, types of employment become the assurance for the housing loan approval process from the bank. This occurred due to the bank which needed assurance in job applicants to ensure the loan repayments run smoothly. A stable employment has leaded to the housing loan approval and increased the homeownership affordability in 270 Danish municipalities (Lauridsen et al., 2008). Besides Denmark, stability employment and duration of employment also enabled lots of professional workers to purchase houses around main cities in China (Gan et al., 2014). A non-stable job and constantly changes will delay the homeownership process to the extent of causing the homeownership to be obtained during the golden age (Cameron \& Tracy, 1997). This is because of the non-stable job affect the household income earned.

Subsequently, the non-stable job also affects the constant monthly payment of housing and non-housing expenditures. Furthermore, self employed households developed fluctuation income throughout the year. Hence, the household tend to use the household savings and make loans to cover up the expenses (Luffman, 2006). For the non-stable job households, affordability would be burdensome till homeownership tended to happen during golden age (Gan et al., 2014). 
Household size factor included the total household which are dependent to the head of household. The children are the dependents to the married status head of household. These clarify the families people prefer owning rather than unmarried people and younger couples without children. The youngsters with single status migrated and created mobility to seek job's opportunity with best income and tend to choose rented dwellings than purchasing (Lauridsen et al., 2008). Therefore, the households aged 40s and above are more likely to purchase a house to establish a stable life (Atterhog, 2005; Bourassa \&Hoesli, 2008). However, in other prospect, a big household size will harden the household to homeownership. The addition of children would affect the changes of life patterns in household (Arimah, 1992; Atterhog, 2005). This is due the number of children increased will be encouraging the life pattern through financial savings especially for the low income group. In addition, large non-housing expenditures needed for each child (Atterhog, 2005).

Moreover, the household size who faced severe wellness issues and disabilities would as well affect the homeownership affordability. This is due the high expenditures spent on treatments, rehabilitations and cares caused bigger household expenditures (Bramley, 2011a). Thus, the supporting services for financials, medicines, tools and reductions of treatment costs from the authorities and voluntary are needed to help reducing the non-housing cost as well as ensuring well progression of housing cost payment for the low income group. If the assistance is not given to this group, it will affect the housing affordability to the extent that the household would tend to sell valuable items to support the treatment costs and daily lives, referring to circumstances in Australia (Yates et al., 2004).

Savings is one of the factors that accelerated the homeownership affordability amongst the low income group. However, this factor still needs deeper analysis as it is one of the optional factors favoured by most of the affordability researchers. Atterhog \& Song (2009) who had done the research on systematic strategies to assure the housing affordability among the low income group found that the savings factor as the effective mechanism to help the low income group to afford a house. Although the income received by this group is rather less, the savings that is done consistently based on the effective savings technique has the potential to reduce the complications of housing affordability in this group. The research on savings was conducted by several researchers such as Worthington (2012) in Australia, Bramley (2011b) in England, Gan et al., (2014) in China, and Nwuba et al. (2015) in Nigeria.

Most households in the developing countries have used vary financial instruments and different sources in formal or informal mechanisms. However, the formal sources are seldom accessed rather than the informal sources which are frequently accessed to obtain a large amount for housing. The financial instruments such as savings, loans and insurances form have helped the low income group in overcoming cash flow problems for a homeownership and reconstructing the existing houses which require large lump sum of money (Porteous, 2011). Besides, the low income group who face difficulties to access housing finance are tend to make own savings aside from negotiating with the close family members and friends (Alaghbari et al., 2011).

The monthly payment for housing is one of the vital essences needed to indicate the affordability. The affordability measurements include the income and housing cost involved. The household is classified as affordable when they spend one fourth of the income for housing 
cost. On the other hand, the household classified as not affordable household if they spend more than one fourth of the income for housing as it will affect the expenditures for other daily necessities. However, the ration differs due to the social environment factors such as the enhancement of living costs (Huchanski, 1995). The affordability concept for the low income group should ensure the escalating house price is relevant to the rental or housing instalments. Rental or housing instalments should not exceed $30 \%$ of the household income. The $30 \%$ include water, gas, electricity, sewage and other utilities. When the monthly housing cost exceed $30 \%$ up to $35 \%$ than the household income, therefore the housing would be labelled as the high rate for the household (Norazmawati, 2007).

\section{METHODOLOGY}

In this research, the sample size chosen from each zone are directly proportional to the zoning size. The Kuala Lumpur City Hall (DBKL) has divided the Kuala Lumpur into four zones to optimise management efficiency. Hence, samples of public housing units will be chosen from the 4 different zones [i.e. zone 1 ( 3700 units), zone 2 (256 units), zone 3 (2283 units) and zone 4 (3048 units)]. The population include the total 9287 units of public housing sold. Due to the different sizes of zones, the samples selection is stratified according to the zoning sizes. Thus, the number of samples in zone 1 is (159 units), zone 2 (12 units), zone 3 (98 units) and zone 4 (131 units) to achieve a total samples of 400 units. The 400 unit's means 400 household head are chosen to be the respondents representing a public housing unit. The PA Seri Kota is selected as zone 1, PA Bukit Kerinchi 1 A as zone 2, PA Seri Perak as Zone 3 and PA Desa Rejang as zone 4 . The chosen areas have the highest public housing units to represent certain zones (DBKL, 2015). After the distributions of the questionnaires, only 365 forms are filled in completely which makes the total selected samples are 365 respondents.

In indicating the affordability level, the residual income theory is used by considering the housing cost and non-housing cost precisely. The affordability levels are categorised by two which is the affordable or not affordable. The household size is classified as 'affordable' if they have positive income residue after their monthly income is deducted with the monthly payment for housing and daily expenditures. However, the household is classified as the 'not affordable' if they have negative income residue after paying for monthly payment for housing and daily expenditures.

The Binary Logistic Regression method used the dichotomous dependent variables consist two values, 0 values or 1 value (Nwuba et al., 2015). This method is competent with the research objective to identify the affordability level whether it is affordable or not affordable. The value of 1 is marked as 'affordable' while the value of 0 is defined as 'not affordable'. The affordability level is the dependent variables in this research. Meanwhile, the independent variables is the factors that affect the homeownership affordability in public housing such as the household income, household expenditures, types of employments, education levels, household sizes, monthly payment for housing (Norazmawati, 2007) and savings (Tan, 2007).

\section{Levels of Affordability}

Table 1 shows homeownership affordability levels for the low income group in Kuala Lumpur is $57.6 \%$. This shown that the low income group who lived in public housing still afford a house. This finding also identifies $42.4 \%$ of the low income group could not afford a house. 
Table 1: The Homeownership Affordability Level

\begin{tabular}{|c|c|c|}
\hline Affordability Level & Respondent & Percentage \\
\hline Affordable & 205 & 57.6 \\
\hline Not affordable & 151 & 42.4 \\
\hline Total & 356 & 100 \\
\hline
\end{tabular}

Source: Authors' Field Work (2015)

\section{Factors affect the homeownership affordability}

This study demonstrates that $38.5 \%$ of the low income group received income at the range of RM 1001 to RM 2000 per month. Besides, 28.9\% received income at the range of RM 2001 up to RM 3000 per month. 19.1\% received income below RM 1000 per month. 10.7\% have an income of RM 3001 to RM 4000 per month and 2.8\% received income which exceed RM 4001 per month (Table 2). This result clearly interpret mean income is RM 2018 while the median income is RM 1950 per month. This findings corroborates the household income is in the low income group makes them eligible to live in public housing.

Table 2: Household Income Percentages

\begin{tabular}{|c|c|c|}
\hline Household income & Respondent & Percentage \\
\hline RM1000 below & 68 & 19.1 \\
\hline RM1001- RM 2000 & 137 & 38.5 \\
\hline RM2001-RM3000 & 103 & 28.9 \\
\hline RM3001-RM4000 & 38 & 10.7 \\
\hline RM4001 above & 10 & 2.8 \\
\hline Total & 356 & 100 \\
\hline
\end{tabular}

Source: Authors' Field Work (2015)

Half of the respondents 50.8\% spend at the range of RM 1001 to RM 2000 for the total expenditures from monthly income. 26.7\% spend at the range of RM 2001 until RM 3000. $11.8 \%$ spend below RM 1000. As much as $10.7 \%$ spend above RM 3001 per month. About 62.6\% spend below RM 2000 from total income for housing expenditures and non-housing expenditures (Table 3). In summary, the total household expenditures are lower than the total household income whereas the mean for household expenditures is RM 1881, and the median of the household expenditures is RM 1695. 
Table 3: Household Expenditures Percentages

\begin{tabular}{|c|c|c|}
\hline Total Expenditures & Respondents & Percentage \\
\hline RM1000 below & 42 & 11.8 \\
\hline RM1001 to RM2000 & 181 & 50.8 \\
\hline RM2001 to RM3000 & 95 & 26.7 \\
\hline RM3000- RM4000 & 32 & 9.0 \\
\hline RM4001 above & 6 & 1.7 \\
\hline Total & 356 & 100 \\
\hline
\end{tabular}

Source: Authors' Field Work (2015)

To facilitate process of the data analysis, type of employments is divided to three categories. The results indicate that $72.5 \%$ respondents work as clerks, administration departments, salesmen and operators. This category requires semi-skilled or low-skilled, including those who work as hawkers in night markets. $24.4 \%$ of the respondents are general workers, retirees and housewives which acquired no skills or only low-skilled. On the other hand, 3.1\% respondents work as the managers, technicians which are considered as high-skilled workers and professional (Table 4). In general, the respondents' occupations are in the low-skilled or semi-skilled categories. For example, the security guards, taxi drivers or store assistants.

Table 4: Type of Employments Percentages

\begin{tabular}{|c|c|c|}
\hline Type of employments & Respondents & Percentage \\
\hline General workers, Housewives & 87 & 24.4 \\
\hline $\begin{array}{c}\text { Clerks, Administration Departments, } \\
\text { Salesmen, Operators }\end{array}$ & 258 & 72.5 \\
\hline Managers, Technicians & 11 & 3.1 \\
\hline Total & 356 & 100 \\
\hline
\end{tabular}

Source: Authors' Field Work (2015)

Based on the educational levels, $66 \%$ received secondary school followed by $24.2 \%$ received non-formal educations or primary school. Non-formal educations include religious educations through pondok or madrasah. The college or polytechnic and university levels which preferred the skills certificates, diploma and degree involved $9.8 \%$ respondents. The graduated respondents from universities, colleges and polytechnics are preferable to the children of the original home owner or technically known as the second generation of public housings' owners. Meanwhile, respondent from secondary school are the first generation homeowners who originally renters according to the terms of low income parallel with low education level. Therefore, the average educational levels are the secondary and primary levels (Table 5). 
Table 5: Educational Levels Percentages

\begin{tabular}{|c|c|c|}
\hline Educational Levels & Respondents & Percentage \\
\hline $\begin{array}{c}\text { Non-formal Educations/ Primary } \\
\text { School }\end{array}$ & 86 & 24.2 \\
\hline Secondary School & 235 & 66.0 \\
\hline College/Polytechnic/ University & 35 & 9.8 \\
\hline Total & 356 & 100 \\
\hline
\end{tabular}

Source: Authors' Field Work (2015)

Based on household size refers schooling and unemployed households who are dependent to the household head, the result shows $24.7 \%$ are having two dependent followed by $23.3 \%$ have one dependent. 21.1\% have three dependent. Nevertheless, $4.8 \%$ are having five dependent in their care. Meanwhile, $1.1 \%$ has six dependent, seven and eight dependent by three respondents or $0.8 \%$. The maximum household size of eight dependent is due to a large number of schooling kids and unemployed wife. In contrast, $7.6 \%$ do not have any dependents which also interpreted either it is a household without child, household with adult children who moved out from the family's residency or both of the spouses are working. In summary, majority household heads or $69.1 \%$ are having one to three dependents.

Table 6: Household size percentages

\begin{tabular}{|c|c|c|}
\hline Household size & Respondents & Percentage \\
\hline None & 27 & 7.6 \\
\hline 1 & 83 & 23.3 \\
\hline 2 & 88 & 24.7 \\
\hline 3 & 75 & 21.1 \\
\hline 4 & 56 & 15.7 \\
\hline 5 & 17 & 4.8 \\
\hline 6 & 4 & 1.1 \\
\hline 7 & 3 & 0.8 \\
\hline 8 & 3 & 0.8 \\
\hline Total & 356 & 100 \\
\hline
\end{tabular}

Source: Authors' Field Work (2015)

The results of this study show that approximately half of the respondents, $47.2 \%$ neither have any savings nor establishing monthly savings. This percentage is not contrary differ to households with savings which is $52.2 \%$ The savings is based on the fixed savings or constants monthly savings in any financial institutions including investment trusted account and insurance (Table 7). 
Table 7: Savings Percentages

\begin{tabular}{|c|c|c|}
\hline Savings & Respondents & Percentage \\
\hline Yes & 188 & 52.8 \\
\hline No & 168 & 47.2 \\
\hline Total & 356 & 100 \\
\hline
\end{tabular}

Source: Authors' Field Work (2015)

For the household heads with savings, 38.8\% made savings below RM 300 monthly. A number of $8.4 \%$ were recorded to make savings between RM 301 to RM 600 . The rest of $5.6 \%$ made savings more than RM 601 monthly (Table 8). For the household who made savings, a large majority of them made savings below RM 300 monthly.

Table 8: Household Total Savings Percentages

\begin{tabular}{|c|c|c|}
\hline Household Savings & Respondents & Percentage \\
\hline None & 168 & 47.2 \\
\hline Below RM300 & 138 & 38.8 \\
\hline RM301 to RM600 & 30 & 8.4 \\
\hline Above RM601 & 20 & 5.6 \\
\hline Total & 356 & 100 \\
\hline
\end{tabular}

Source: Authors' Field Work (2015)

The monthly payment for housing has two notable categories, either the settled monthly payment for housing due purchasing house in cash or monthly payment in hundreds by household heads. More than half of the household heads purchased the house in cash which is $55.3 \%$. Meanwhile, the rest of $44.7 \%$ paid the monthly payment. $23.3 \%$ paid the monthly payment between RM 201 to RM 300, 11\% paid RM 301 to RM 400, 9\% paid below RM 200 and only $1.4 \%$ paid the monthly payment for housing over RM 401 per month (Table 9).

Table 9: Monthly Payment For Housing Percentages

\begin{tabular}{|c|c|c|}
\hline Monthly payment for housing & Respondents & Percentages \\
\hline Below RM 200 & 32 & 23.3 \\
\hline RM 201 to RM 300 & 83 & 11 \\
\hline RM 301 to RM 400 & 39 & 1.4 \\
\hline Above RM 401 & 5 & 55.3 \\
\hline By Cash & 356 & 100 \\
\hline Total & 357 & 9 \\
\hline
\end{tabular}

Source: Authors' Field Work (2015)

Table 10 shows the final result for the seven independent variables used to indicate factors that affect the homeownership affordability for the low income group in Kuala Lumpur public housing. Surprisingly, the analysis figured out only three factors affected homeownership 
affordability significantly such as the household income, household expenditures and monthly payment. Conversely, education level, types of employment, household size and household savings not affects homeownership affordability significantly. The high household income brings positive impact to the homeownership affordability as it is able to boost the housing affordability whereas the low household income will affect the housing affordability. The high household expenditures bring negative impact to the homeownership affordability because the high expenditures for housing cost and non-housing cost will affect the housing affordability. However, if either the expenditures be reduced, the chances of homeownership affordability will increase. Meanwhile, the high monthly payment for housing brings negative impact to the homeownership affordability. This is due to the high monthly payment could affect the housing affordability because the high monthly payment will reduce the non-housing expenditures for daily life such as foods, education, health care and transportations.

TABLE 10: VARIABLES IN THE EQUATION

\begin{tabular}{|c|c|c|c|c|c|c|c|}
\hline & Variables & B & S.E. & Wald & Df & Sig. & Exp(B) \\
\hline Step & $\begin{array}{c}\text { Type of } \\
\text { employments }\end{array}$ & & 5.011 & 2 & .082 & \\
\hline $\begin{array}{c}\text { Type of } \\
\text { employments (1) }\end{array}$ & 1.639 & 1.409 & 1.353 & 1 & .245 & 5.152 \\
\hline $\begin{array}{c}\text { Type of } \\
\text { employments (2) }\end{array}$ & 3.372 & 1.625 & 4.307 & 1 & .038 & 29.132 \\
\hline & $\begin{array}{c}\text { Education levels } \\
(1)\end{array}$ & -.867 & .953 & .828 & 1 & .363 & .420 \\
\hline & $\begin{array}{c}\text { Education levels } \\
(2)\end{array}$ & .530 & 1.706 & .097 & 1 & .756 & 1.699 \\
\hline & $\begin{array}{c}\text { Education levels } \\
\text { Household } \\
\text { income }\end{array}$ & .027 & .006 & 18.292 & 1 & .000 & 1.028 \\
\hline $\begin{array}{c}\text { Monthly payment } \\
\text { for housing }\end{array}$ & -.006 & .003 & 4.316 & 1 & .038 & .994 \\
\hline & Total expenditures & -.026 & .006 & 17.952 & 1 & .000 & .974 \\
\hline Savings & -1.562 & .978 & 2.548 & 1 & .110 & .210 \\
\hline Household Size & -1.829 & 1.004 & 3.318 & 1 & .069 & .161 \\
\hline
\end{tabular}

Indicator : Affect Variables $=<0.05$. Not Affected Variables $=>0.05$.

Source: Authors' Field Work (2015)

\section{CONCLUSION}

Based on the findings and discussions on the housing affordability level and factors affected homeownership affordability for the low income group in Kuala Lumpur public housing, it could be concluded that housing affordability is a complex and involved the integration between the homeownership affordability factors to ensure the household could always being able to strengthen and enhance the homeownership affordability. The house is not only for shelter, but homeownership tend to affect household through job involvement, access to employment and facilities, family happiness and educational achievement. Hence, the goal to 
improve and increase homeownership affordability should be assisted along with the government policies and empowered with the household's action.

One of the ways to tackle the affordability issue is by income increment. Therefore, income increment could be done by doing additional employments or part time job. However, the additional employments depend on the current economy markets because the unstable economy is likely to force the household losing their additional jobs. Hence, the side income jobs could be done by making online business deals which are indirectly encouraging the entrepreneurship sector in the country. Although it is a small business, if it could be expanded then the businessman would be employing workers for smoothing businesses. Therefore, the usage of labour would highly increase and indirectly reduced unemployment rate as well as boosting up the domestic economy. Despite affordability could be improved by additional employments, the married household should also give attention to the family members particularly their kids. The excessive attention given to the main and additional employments could affect the quality times with the children who need attention and support from parents for healthy growth. The abandoned children from the low income families due to hectic working schedule had affected their education performances and increase social violence issues as occurred in Canada (Hulchanski, 2002). Hence, the idea of focusing on work should be directly proportional with the focus on families.

Furthermore, government's intervention is highly needed to tackle affordability issues through the subsidized housing provision for the low income group especially in the cities. Provision of more subsidized housing has created opportunities for large number of the low income household become homeowners plus ensuring sustainable housing affordability and daily expenditures. Homeownership with subsidized prices encourages the housing cost reduction among the low income group. For instance, the market rental payment RM 800 per month is deducted to RM 400 monthly payment for homeownership. By this deduction, the residue income could be used to other vital expenditures such as education for children, healthcare and transportations. In addition, the presence of the income residue would increase the housing affordability and enhancing the purchasing power in this group.

Thus, despite of controlling the house prices mainly in the city, policy initiatives and interventions is essential to reduce the non-housing cost of the low income group. The nonhousing costs include the foods, transportations, apparels, health care and education. The accelerating of living cost in the city through the increasing daily necessities prices would affect the homeownership affordability of low income group if the household income is not been upgraded. The efficiency of public transportation system in low rate, constant surveillance from the authorities of the price increases are the steps towards the enhancement of homeownership affordability for the low income group.

\section{References}

Alaghbari, W., Salim, A., Dola, K., \& Ali, A. A. A. (2011). Developing affordable housing design for low income in Sana'a, Yemen. International Journal of Housing Markets and Analysis, 4(1), 84-98. doi:10.1108/17538271111111857

Arimah, B. (1992). Hedonic Prices and the Demand for Housing Attributes in a Third World City: The Case of Ibadan, Nigeria. Urban Studies, 29(5), 639-651. doi:10.1080/00420989220080601

Atterhog, M. (2005). Importance of government policies for home ownership rates An international survey and analysis. Swedish Royal Institute of Technology Stockholm.

Atterhog, M., \& Song, H. (2009). A Survey of Policies that may Increase Access to Home Ownership for Low Income Households. Housing, Theory and Society, 26(4), 248-270. doi:10.1080/14036090802614479 
Bentzien, V., Rottke, N., \& Zietz, J. (2012). Affordability and Germany's low homeownership rate. International Journal of Housing Markets and Analysis, 5(3), 289-312. doi:10.1108/17538271211243616

Bentzinger, A. L., \& Cook, C. C. (2012). On The Path To Homeownership: Low Income Owners And Renters In Rural Communities. Housing and Society, 39(1), 77-98.

Boehm, T. P., \& Schlottmann, A. M. (2004). The dynamics of race, income, and homeownership. Journal of Urban Economics, 55(1), 113-130. doi:10.1016/j.jue.2003.08.001

Bourassa, S. C., \& Hoesli, M. (2008). Why Do the Swiss Rent? The Journal of Real Estate Finance and Economics, 40(3), 286-309. doi:10.1007/s11146-008-9140-4

Bramley, G. (2011a). Affordability, poverty and housing need: triangulating measures and standards. Journal of Housing and the Built Environment, 27(2), 133-151. doi:10.1007/s10901-011-9255-4

Bramley, G. (2011b). Affordability, poverty and housing need: triangulating measures and standards. Journal of Housing and the Built Environment, 27(2), 133-151. doi:10.1007/s10901-011-9255-4

Burke, T., \& Ralston, L. (2004). Measuring housing affordability. Australian Housing and Urban Research Institute, (45).

Cameron, S., \& Tracy, J. (1997). The Transition to Homeownership : The Importance of Early Career Concerns, (April).

Chaplin, R., \& Freeman, A. (1999). Towards and accurate description of affordability. Urban Studies, 36(11), 19491957.

DBKL Dewan Bandaraya Kuala Lumpur. (2015). Jabatan Pengurusan Perumahan dan Pembangunan Komuniti: Kuala Lumpur.

Follain, J. R., \& Ling, D. C. (1988). Another Loook at Tenure Choice, Inflation and Taxes. AREUEA Journal, 16(3).

$\mathrm{Fu}, \mathrm{Q}$. (2015). The persistence of power despite the changing meaning of homeownership: An age-period-cohort analysis of urban housing tenure in China, 1989-2011. Urban Studies. doi:10.1177/0042098015571240

Gabriel, M., Jacobs, K., Arthurson, K., Burke, T., \& Yates, J. (2005). Conceptualising and measuring the housing affordability problem. Australian Housing and Urban Research Institute, (May).

Gan, C., Hu, B., Gao, C., Kao, B., \& Cohen, D. a. (2014). An empirical analysis of homeownership in urban China. Journal of Asia Business Studies, 8(1), 1-17. doi:10.1108/JABS-01-2012-0005

Goodman, A. (1988), "An econometric model of housing price, permanent income, tenure choice and housing demand", Journal of Urban Economics,Vol. 23, pp. 327-54

Haurin, Donald R. (1991). Income Variability, Homeownership, and Housing Demand. Journal of Housing Economics, 1, 60- 74

Hulchanski, J. D. (1995). the Concept of Housing Affordability - 6 Contemporary Uses of the Housing ExpenditureTo-Income Ratio. Housing Studies, 10(4), 471-491. doi:10.1080/02673039508720833

Hulchanski. (2002). Housing Policy for Tomorrow's Cities. Canadian Policy Research Networks Inc, (December), $1-40$.

Kupke, V., \& Rossini, P. (2011). Housing affordability in Australia for first home buyers on moderate incomes. Property Management, 29(4), 357-370. doi:10.1108/02637471111154809

Kutty, N. K. (2005). A new measure of housing affordability: Estimates and analytical results. Housing Policy Debate, 16(February), 113-142. doi:10.1080/10511482.2005.9521536

Lauridsen, J., Nannerup, N., \& Skak, M. (2008). Dynamic and Geographic Variation in Determinant Effects on Home Ownership. Discussion Papers on Business and Economics, 5.

Luffman, J. (2006). Measuring housing affordability. Perspective. Canada.

Mohit, M. A., \& Nazyddah, N. (2011). Social housing programme of Selangor Zakat Board of Malaysia and housing satisfaction. Journal of Housing and the Built Environment, 26(2), 143-164. doi:10.1007/s10901-011-9216-y 
Norazmawati, M. S. (2007). Kemampuan pemilikan rumah kos rendah di Kuala Lumpur. Thesis Ph.D, Universiti Sains Malaysia, Pulau Pinang.

Nwuba, C. C., Kalu, I. U., \& Umeh, J. a. (2015). Determinants of homeownership affordability in Nigeria's urban housing markets. International Journal of Housing Markets and Analysis, 8(2), 189-206. doi:10.1108/IJHMA-062014-0020

Porteous, D. (2011). Housing Finance and Financial Inclusion. In D. Köhn \& J. D. Pischke (Eds.), Housing Finance in Emerging Markets: Connecting Low-Income Groups to Markets (pp. 7-48). Berlin, Heidelberg: Springer Berlin Heidelberg. doi:10.1007/978-3-540-77857-8

Robinson, M., Scobie, G. M., \& Hallinan, B. (2006). Affordability of Housing : Concepts , Measurement and Evidence (No. 06/04). New Zealand, New Zealand.

Scalon, K., \& Whitehead, C. (2004). International trends in housing tenure and mortgage finance. London: The Council of Mortgage Lenders (CML).

Retrievedfromwww.cml.org.uk/cml/filegrab/pdf_pub_resreps_51full.pdf.pdf?ref=3870

Stone, M. E. (2006a). A Housing Affordability Standard for the UK. Housing Studies, 21(4), 453-476. doi:10.1080/02673030600708886

Stone, M. E. (2006b). What is housing affordability? The case for the residual income approach. Housing Policy Debate, 17(1), 151-184. doi:10.1080/10511482.2006.9521564

Tan, T. H. (2007). Determinants of Homeownership in Malaysia. Multimedia University.

Tang, C. P. Y. (2012). Measuring the affordability of housing association rents in England: a dual approach. International Journal of Housing Markets and Analysis, 5(3), 218-234. doi:10.1108/17538271211243571

Thalmann, P. (2003). "House poor" or simply "poor"? Journal of Housing Economics, 12(4), 291-317. doi:10.1016/j.jhe.2003.09.004

Turner, T. M., \& Luea, H. (2009). Homeownership, wealth accumulation and income status. Journal of Housing Economics, 18(2), 104-114. doi:10.1016/j.jhe.2009.04.005

Worthington, A. C. (2012). The quarter century record on housing affordability, affordability drivers, and government policy responses in Australia. International Journal of Housing Markets and Analysis, 5(3), 235-252. doi:10.1108/17538271211243580

Yates, J., Berry, M., Burke, T., Keith Jacobs, Milligan, V., \& Randolph, B. (2004). Housing affordability for lowerincome Australians : plan. Australian Housing and Urban Research Institute, (August). 